\title{
NEIGHBOURHOOD AND SOCIOCULTURAL VALUES IN THE LITHUANIAN RITUAL YEAR
}

\author{
Rasa Paukštytè-Šaknienè \\ Department of Ethnology and Anthropology, Lithuanian Institute of History, \\ Vilnius, Lithuania \\ e-mail: rasa.sakniene@gmail.com
}

\begin{abstract}
Research into the community customs in the second half of the $20^{\text {th }}$ century and the early $21^{\text {st }}$ century in villages, towns, and cities near Vilnius allowed to distinguish two types of neighbourhoods: distant (official) and close (informal) ones. The first one was determined by territorial proximity, the second is revealed in more than just territory. The former is exposed also as a group formed around common interests, people, who are free to choose to spend leisure time or celebrate special occasions together. The festive communication results in sort of a ritual year of the neighbours, covering the common neighbours' celebrations of life cycle as well as calendric cycle festivals and holidays. A close neighbourhood based on spending leisure time and celebrating together in some cases determines certain differences between neighbours of different religions. I'll look at this process analyzing different types of settlements, showing the development of neighbourhood relations during the last 60 years.
\end{abstract}

Keywords: neighbourhood, religion, ritual year,sociocultural values, town, village

\section{Introduction}

It is difficult to talk about the ritual year in contemporary society, especially in a multicultural environment where a combination of religious, state and 
entertainment-oriented festivals are celebrated by people of different religions and nationalities (cf. Laučkaitė 2009: 27). However, rituals and celebrations have retained an important social meaning in modern society. As Ursula Rao mentioned, "rituals serve important functions for the organisation and reorganisation of social contexts. It's like a medium for the integration of society, and interestingly, this idea remains important even where attention is shifted to conflict and change" (Rao 2008: 143). In this article, I shall analyze the relationship between contemporary local neighbourhood communities and the ritual year, which has not yet been investigated in the Lithuanian context.

The neighbourhood is a very wide concept with multiple ways of being understood that is used in research by geographers, historians, sociologists, lawyers, architects, anthropologists, and ethnologists. From the perspective of ethnologists, the notion of neighbourhood balances between a geographical concept and a value category. When analyzing the formation of a community, Ferdinand Tönnies distinguished three types - based on family relations, neighbourhood and friendship, and using friendly connections to achieve specific common goals. According to the researcher, the concept of neighbourhood dates back to a common life in rural surrounds, with short distances between buildings, and common meadows/pastures which determined tight links and communication between people (Tönnies 2001: 28). Werner Rösener, who has studied the culture of European peasants, also indicated that village structures and the inner relations within a community were also affected by neighbourhood links, which were considered the main factor in the development of peasant communities (Rösener 2000: 173-174). In all European countries, the neighbourhood was the main element of communication among peasants. Note that the introduction of three-field crop rotation played a significant role in the formation of neighbourhood links. This and other similar land use systems were adopted in villages in the $11^{\text {th }}-14^{\text {th }}$ centuries in a majority of Western European countries. In Eastern Europe on the other hand, a multiple-field form of farming became widespread only in the $15^{\text {th }}-16^{\text {th }}$ centuries, or even later (Rösener 2000: 174). Wherever it was adopted, this kind of farming system soon began to dominate, and peasants were forced to cooperate more than they had previously. The peasant way of life formed a particular kind of community awareness in villages, which could be described using the words "good neighbourly relations". According to the author, small villages and their cosy surrounds created a family atmosphere, which was further strengthened by the more frequent marriages between village members, people worked alongside one another, 
attended church together and celebrated village festivities together (Rösener 2000: 179). In Lithuania, three-field crop rotation and changes to the village planning structure are related to the Volok Reform, introduced in the second half of the $16^{\text {th }}$ century, which lasted until the beginning of the 17 th century (Puodžiukienè 2014: 15). According to the ethnologist Auksuole Čepaitiené, the neighbourhood is a form of social commonality based on shared territory and living in close proximity to other members of the same group. It is also an interpretation of social relations, values and daily practices (Čepaitiene 2013: 395). In the $19^{\text {th }}$-early $20^{\text {th }}$ centuries in Lithuania, the neighbourhood was associated with one's living surrounds and interpersonal communication and relationships, mostly based on mutual social assistance in labour and in case of accidents, common farm and other work, the loaning of necessities (fire, bread, grains for sowing), sharing, and also honourable behaviour and the protection of one another's property (Mažiulis 1940: 242-246; Mažiulis 1941: 91-96; Vyšniauskaitè 1964: 527-550). In Lithuania, it was often said that "a good neighbourhood is better than kinship".

This article is based on field research conducted by the author in Vilnius, Trakai and Širvintos districts (all of these districts belong to Vilnius county) in 2017 and 2018 in locations of different sizes, and of various ethnic and religious composition. During the fieldwork, the semi-structured interview method was used with 44 respondents born between 1934 and 1991.

Three villages were under investigation: Medininkai (a population of 493 according to statistical data from 2011), Marijampolis (870) and Nemėžis $(2,498)$. Nemèžis has already become a suburb of Vilnius. Medininkai, a location near the Lithuanian-Belarusian border, is famous for its remarkable past; the Medininkai Castle near the village dates back to the $14^{\text {th }}$ century and continues to attract tourists, while the castle museum is the employer of a number of the local villagers. Marijampolis is known for its Lithuanian school which was attended by children from both the Vilnius District and by Lithuanian children from the Lithuanian ethnic lands in Belarus. Respondents in Marijampolis were Lithuanians and Poles (all Catholics); in Medininkai - Poles and a Belarusian woman (Catholic) and a Russian man (Christian Orthodox) were interviewed; in Neméžis interviews were conducted with Poles (Catholics), Tatars (Muslims), and a Russian woman (Christian Orthodox). Cities of different sizes were also researched: Kernavè (a town), Trakai and Nemenčinè (cities). Kernavè was an important centre in the Grand Duchy of Lithuania, while now it is just a local eldership (seniūnija - the smallest current administrative-territorial unit in 
Lithuania) centre. Trakai was the former capital of Lithuania (before Vilnius became the capital in 1323) and is the only one of these cities that is a district municipality centre. Like Kernave, Trakai is an important tourist attraction. According to statistical data of 2011, Kernavè has a population of 272, Nemečinè has a population of 4,613, and Trakai has a population of 4,933. All the respondents interviewed for this research in Kernave were Lithuanians (Catholics); in Trakai - Lithuanians and one Polish woman (Catholics), Karaims (Karaim), and a Belarusian woman (Christian Orthodox); in Nemenčine - Lithuanians and Poles (Catholic), and a Russian woman (Christian Orthodox).

The current Law on Religious Communities and Associations in the Republic of Lithuania (No. I-1057, October 4, 1995) distinguishes nine traditional religions. Alongside the Christian Roman Catholic, Greek Catholic, Evangelical Lutheran, Evangelical Reformed, Orthodox, and Old Believer faiths, the state also supports the Jewish, Sunni Islam, and Karaim religions. Thus, the respondents who were surveyed represent five of these confessions. The dominant ethnic groups in Lithuania according to population figures are Lithuanians, Poles, Russians and Belarusians (respectively 84.2; 6.6; 5.8 and 1.2 percent). Karaims and Tatars were also interviewed, who, according to Ives Plasseraud, hold a historically important place in the Lithuanian space (Plasseraud 2006: 130). This fact makes it possible to look at the situation in the researched locations from a multicultural aspect.

The selection of these particular research locations was determined by the Lithuanian Institute of History's research program "Leisure, Festivals, and Rituals in the Vilnius Area: Social and Cultural Aspects". The aim of this program is to answer the question of how shared leisure time, celebrations and rituals help maintain social interaction between settlements of different types, and different ethnic and confessional composition, and to reveal the cultural expression of this process over the perspective of time. Analysis of neighbourhood links helps the scholars to answer the question whether, and if so, how have neighbourly relations maintained their social significance in various kinds of locations in Lithuania. As the research was conducted in poly-ethnic and polyconfessional environments, I had the opportunity to work out whether ethnic or confessional belonging was important to the intensity of communication and friendship between neighbours. The ritual year - as a space bringing neighbours together - was the background chosen for this research. In this article, I seek to analyse the neighbourhood not just as a territorial or economic necessity, but as a group bound out of common interests, which is determined by the free 
choice of neighbours and the communication and friendship of its members during family and calendar celebrations ${ }^{1}$.

The respondents were randomly selected, without discriminating for gender, nationality, or age. Going from door to door, I asked all adult individuals who agreed to answer my questions about their personal views on neighbourhood, their mutual communication, and friendship at various stages in life. The interviews took place in Lithuanian or Russian, and when necessary, some terms were translated into Polish.

\section{Studies of Neighbourhood}

As Zygmunt Bauman noted, the term "community" is one of those words that arouses good feelings (Bauman 2001). On the other hand, as Thomas Hyland Eriksen argued, "in fact virtually no local community is completely self-sustaining and unchanging through time" (Eriksen 2001: 58). According to the study by Andželika Bylaitė-Žakaitienè, the geographical and social mobility that commenced in the second half of the $20^{\text {th }}$ century, the decreased levels of experience of the older generation, the disappearance of the community's authority, and the responsibility for the behaviour of its members destroyed the community neighbourhood traditions that had dominated in Lithuanian villages up to the mid- $20^{\text {th }}$ century. As distance in personal relations appeared, utilitarian values also seemed to take on shades of alienation in certain cases, thereby changing neighbourly relations and norms (Bylaitė-Žakaitienè 2012: 282).

It would appear that the neighbourhood was important only in terms of the traditional, pre-collectivisation Lithuanian village. However, according to Teodor Shanin, even collective and commune-like communities maintained a number of the typical features of a peasant community (Shanin 1990: 45). What situations unfolded in the contemporary Lithuanian village, town, or city?

Numerous studies have been conducted in Lithuania that unveil the features of neighbourhoods in $19^{\text {th }}$ - and early $20^{\text {th }}$-century Lithuania. However, the pioneer in systematic neighbourhood research would be Antanas Mažiulis, who studied interpersonal relations (in the early 1940s in Lithuania, and later on as in immigrant in the United States). When describing the interpersonal relations in the Dusetos and Kamajai small rural districts (North East Lithuania) in the late $19^{\text {th }}$ - early $20^{\text {th }}$ centuries, the author dedicated several articles to neighbourhood traditions. Mažiulis' greatest contribution to neighbourhood research historiography was distinguishing between the concepts of the "close" and the 
"great" neighbourhood. A close neighbourhood (also known as a "savybè", Lit. 'a quality') was usually defined as two or three of the nearest yards, or properties, that maintained particularly close links. For example, if someone came over to borrow an item, but did not find their neighbour at home, the required item could be taken without asking, and the neighbour could be informed of what had been borrowed that evening. These kinds of savybe neighbours also often jointly kept bees and maintained common beehives, they were godparents to each other's children, and would attend the same bathhouse. One neighbour's misfortune was another neighbour's misfortune; it was experienced together and they would help one another in times of need. The greater neighbourhood, which encompassed a small village or part of a larger village, was in most cases not very close, and existed "more out of dependence than out of sincerity" (Mažiulis 1957: 244). This implies that the neighbourhood can be related to trust and to deeper feelings.

Only a handful of papers have been dedicated to the research of current neighbourhood links in Lithuania, from which I would draw attention to a study conducted in North East Lithuania. This work compares the situation in Kupiškis and nearby rural locations, as well as the cooperation among neighbours of different nationalities. Having completed this research, Egle Udraitè stated:

When I spoke to those respondents from these villages, I noticed that their concept of a neighbour was somewhat different to the responses coming from city dwellers. They viewed a neighbour as someone who just happened to live right nearby. In villages, the communication between people who lived near one another was usually more active than in the cities.

Meanwhile, in the city, in Kupiškis, according to the author:

... the following kind of concept of a neighbour became apparent: a neighbour is not just someone who lives nearby, but also someone who might live in the same street, or sometimes even a little further away, with whom one would meet quite often to chat, have fun, help one another, or come together to do their work...

However, according to the author, in various types of locations, neighbourly relations with people of different nationalities did not diverge. Youth of different nationalities went to dance together in their free time (Udraitè 2016: 920-924). 


\section{The Close and Distant Neighbourhoods}

The research conducted in the villages of Marijampolis and Neméžis, and the town of Kernave, revealed that neighbourly relations are based on social assistance and a sense of obligation towards people living nearby. This form does not change much over time and encompasses mutual assistance in taking care of children, animals and household items; carrying out compulsory work around the house and farm, providing emotional and financial support in the event of illness or death of a close one, loaning things, and participating in communal work (Paukštytė-Šaknienè 2018: 35-62). On the other hand, in these locations, good relations between neighbours was not limited only to fundamental social assistance. A similar situation was found to exist when the research was extended into the cities of Nemenčine and Trakai.

According to a Karaim woman from Trakai who was born in 1951, a "neighbourhood is first of all help, but not only when something goes wrong. It is friendship when you want to share your joy with others. All of my neighbours are like friends. Good relations with neighbours lead to friendship and understanding". The respondent believes that she adopted the tradition of getting along well with her neighbours from her grandparents. According to the woman, "you need to be nice to everyone, and shouldn't keep a stone ready behind your back, so to say. Neighbours are like family, as they are near, while relatives are far away". A Lithuanian woman born in 1956 from Trakai made similar comments, however she also distinguished the bad neighbour category. She said that "there were good and bad [neighbours], who did not want to be friends". But according to a Lithuanian woman from Nemenčinè born in 1947, the whole street full of neighbours was like family. In her view, perhaps three years ago everyone was much closer, but her older age did leave an impact. Now, she was "more friendly" with six or seven families, yet she did not equate her neighbours to friends. As the respondent said, "friends are friends, while neighbours are just that, i.e., a neighbour is a neighbour, not a friend". A Lithuanian woman born in 1952 from Trakai placed great significance on the assistance offered by neighbours in the protection of property: "a neighbourhood is good, e.g., if you need to go away somewhere - one would say "we want to hand over our home", i.e., to ask someone to look after your place". A Lithuanian woman from Nemenčinè born in 1954 said that "you need to get along well with your neighbours, because it's like being part of a family - not getting along is not an 
option". The research in the village of Medininkai revealed a similar situation. According to a Polish woman born in 1969, "neighbourhood is when you can trust those people. Earlier, you would take your daughter over to the neighbours to be looked after for a while, or drive them where they needed to go, or would help one another with any concerns. Now, there are no good neighbours left around here. There are alcoholics you just don't want to have anything to do with". A Russian Orthodox man born in 1963 from the Medininkai village said that he got along well with neighbours everywhere, and that "neighbours are people who can help one another".

When analysing the situation in the locations studied in the second half of the $20^{\text {th }}$ and the early $21^{\text {st }}$ centuries, I reached the conclusion that people's attitudes towards neighbours and the neighbourhood can be distinguished into several groups: 1) good neighbourly relations are just as important as friendship and even kinship; 2) good neighbourly relations are not as important as family relations or friendship; 3) good neighbourly relations are not important at all. The first group of people usually associate good neighbourly relations not just with interpersonal relations, but also with the pleasure gained in being together. The second, and sometimes respondents representing the third group, think that good neighbourly relations are only associated with obligatory mutual assistance. Thus, I distinguished two types of neighbourly relations: 1. distant (official) and 2. close (informal) neighbourly relations. The first is determined by territorial proximity, the second represents a group formed around territory and common interests, which rests on the independent choice of each participating neighbour. Distant neighbourly relations are based solely on social assistance and obligations towards the people living nearby. Aside from social assistance and obligations towards neighbours, close neighbourly relations involve other links unrelated to social assistance and non-obligatory daily and festive interaction. The result of these kinds of neighbourly relations is interaction between neighbours during leisure time, as well as in the perspective of calendar and life cycle celebrations, which will be discussed in the next section.

\section{The Ritual Year and Close Neighbourly Relations}

The locations researched in this study are of mixed confessions. The respondents belong to different confessions which celebrate different festivals, in particular Tatars and Karaims who belong to the non-Christian confessions (they profess 
the Islamic and Karaim faiths). Their celebrations and customs are very different from the celebrations and customs of people belonging to the Christian religions. On the other hand, the number of Karaims and Tatars is not so great, they do not live in a compact area (an exception could be Karaimų Street in Trakai where several Karaim families still live ${ }^{2}$ ) and in most cases, they live surrounded by people professing one of the Christian faiths. However, based on the research conducted by Žilvytis Šaknys in Vilnius, as the number of mixed-faith families grows, the celebrations of different faiths end up being marked. For example, a Karaim woman from Vilnius indicated Kūčios, or Christmas Eve, as the second most important celebration after Tymbyl chydžy (the Karaim Easter), as her daughter-in-law was a Catholic, she would spend this celebration with her children, while on New Year's Eve she would look after her grandchildren (Šaknys 2019: 261). As Jonas Mardosa noticed, the main Catholic calendar celebrations and the celebrations of most significant political dates for Lithuanians are dominating in the multicultural Vilnius. The entertainment-related part of these celebrations facilitate their celebration as the people at large are drawn to public events regardless of their nationality or religious identification (Mardosa 2013: 58). This makes it possible for neighbours of different religions to share common celebrations. However, unlike the situation in the capital city, the data from the locations I studied showed that neighbours of different confessions often mark non-religious calendar and family celebrations together.

The holiday most commonly celebrated together with one's neighbours is January $1^{\text {st }}$ - New Year's Day, which is an important festival for neighbours of various nationalities and confessions. Even though Muslims and Karaims celebrate the New Year at a different time, and the Orthodox and Old Believers celebrate it according to the Julian calendar, January 1st does make everyone in the researched locations come together. This is the most stable state celebration marked in the researched locations that belonged to the Russian Empire, Poland, the Soviet Union, Nazi Germany, and the Republic of Lithuania (Šaknys 2016: 258). During the Soviet period, this celebration was given particular significance in order to push aside the religious-focused Christmas celebration (PaukštytèŠaknienè 2016: 24). For example, a Karaim woman from Trakai born in 1951 reported that in her street, the tradition of wishing neighbours a "Happy New Year" by going from door to door exists even today. According to the woman, she gets along equally well with neighbours of other nationalities. A Tatar male born in 1959 who lived in an apartment building in the village of Nemežis explained, how at midnight on New Year's Eve, the neighbours would all come out into 
the stairwell to drink champagne together. An account by a Lithuanian woman from Kernave (born in 1966) was also similar - the neighbours who wanted to, would gather with their families at midnight on New Year's Eve by a pine tree on their street to pop a bottle of champagne. People would wish one another "Happy New Year" and then go back to continue celebrating separately at their own homes. Thus, in the villages, towns, and cities researched in this study, a New Year's Eve tradition that exists to this day is to go out with champagne into the street, by a pine tree or a bonfire, and let off fireworks at midnight. After midnight, some people sometimes invite their neighbours to continue celebrating back at their homes. However, certain changes to this tradition are evident. As a Lithuanian woman from Nemenčinè born in 1947 explained, the neighbours in her street (who lived in separate, private houses) would gather in the forest or other natural surroundings to celebrate the New Year. In earlier years, around 30 people, adults and children, would gather. They would choose someone to play Grandfather Frost and his female partner Snow Girl, and think of different ways to entertain themselves - everyone would bring some food, it would be set out on a sledge for everyone to share, and later everyone would take turns riding the sledge down the hill. The woman recalls it was lots of fun, however these traditions are disappearing because young people more often choose to celebrate New Year's Eve with their friends, rather than with their neighbours, and the older people come out for this gathering more rarely. A Lithuanian woman born in 1954 from Marijampolis, also said that it was a shame that neighbours no longer gathered at the same fir tree with champagne like they used to twenty years ago.

International Women's Day is a celebration held together with one's neighbours. It was most intensively observed up to 1990 when neighbours would exchange cards, men would give their female neighbours flowers, sometimes whole families of closer-knit neighbours would gather to mark this day. A Belarusian woman born in 1982 from Medininkai also mentioned special community celebrations. Neighbours from their street would bring a huge table to the Autumn Festival held in the Medininkai Castle, everyone would bring food and drinks, and try one another's food. Groups of neighbours from nearby streets would have similar tables where everyone would bring food and drink. Other celebrations with a Christian element, like the second day of Christmas, Easter Monday, or St. John's Day would also be an opportunity to get together with neighbours who were Catholics or professed other Christian faiths. According to a Polish woman born in 1974 from Neméžis, neighbours would 
go around visiting one another on the second day of Christmas and Easter Monday, while everyone would celebrate St. John's Day outside in natural surrounds. A Lithuanian woman born in 1947 from Nemenčinè explained how she and her neighbours celebrated St. John's Day together. People from their street (and other streets) would gather by a stream and light a bonfire. There would be lots of fun and games.

Parish feast days also sometimes gathered Catholics and neighbours of different nationalities (Lithuanians, Poles, Belarusians). A Belarusian woman born in 1982, who was a Catholic from Medininkai, recalled a lot about the Feast of the Holy Trinity during which neighbours from one or several streets would collect money and decorate the interior of their church.

A Lithuanian woman born in 1947 from Nemenčinè said preparation ahead of certain celebrations would bring neighbours closer to one another. Everyone would come together to help out in cleaning up their immediate surrounds. For example, before Easter, neighbours would decide on a day where they would pick up litter, clean up the surrounding yard, and then bring food and drink to share after the work was done.

Birthdays are unquestionably the most important occasion out of the life cycle celebrations when neighbours of different nationalities and religions would come together. A Belarusian woman born in 1982 from Medininkai said that good neighbourly relations were related to visiting one another not just on ordinary days, but especially on birthdays: "Some just say hello and that's it, but others are much closer, especially when neighbours' children play with one another. Then they visit one another, celebrate birthdays together. Closer neighbours often come over uninvited to wish their neighbours a "happy birthday", and then they're asked to join on in the party." In some cases, neighbours would only come over if they were invited. According to a Tatar woman born in 1945 from Nemèžis, when her generation was much younger, everyone was much closer to their neighbours. It was quite acceptable to invite not just one's relatives to a family celebration, e.g., a birthday, but closer neighbours as well. Not inviting them would have been considered rude. When special anniversary birthdays were being celebrated, even more neighbours would be invited. However, as the respondents noted, in recent years birthdays are being celebrated more and more often at restaurants where only family members and friends are invited, but not necessarily neighbours. According to the recollections of a Lithuanian woman from Nemenčine born in 1947, when she celebrated her $50^{\text {th }}$ birthday, she invited both, her relatives and her neighbours. 
She said "now it is difficult to organise something like that at home. Everyone goes to a cafe or restaurant, and they end up inviting less guests". People keep in contact with their neighbours in ways such as that described by a woman from Kernave born in 1966, where even though she lives near and is rather close to several neighbouring women, they congratulate one another on their birthdays by sending SMS messages or by telephone.

Name days are rarely celebrated with neighbours, even though they are likely to pass on their wishes to that person if they share the same faith. According to a Lithuanian woman from Nemenčine (born in 1981), she always goes to congratulate her neighbour Antanas (Anthony) on his name day. A Lithuanian woman born in 1959 from Kernave also mentions going to wish her neighbours well on the occasion of their name days. But another Lithuanian woman from Kernave born in 1953 said how her husband Jonas (John) would only receive well-wishes during the Soviet years, and that now this tradition had disappeared.

The respondents mentioned common celebrations of children's baptisms, or the seeing-off of youths recruited into the army, and more often - at weddings and funerals. As the research showed, the mentioned events in people's life cycles could bring neighbours of different faiths closer to one another. For example, a Russian woman born in 1934 from Nemenčinè would always attend her neighbours' funerals regardless of their faith. A Polish woman born in 1954 from Neméžis spoke about a case where, when her neighbour's son, a Tatar, died, she helped clear his room after the funeral and would sometimes invite the woman over for a visit, to help her cope with the loss of her son (even though they had not been close neighbours before his death). A Polish woman from Marijampolis born in 1956 indicated she had helped her neighbours prepare food for weddings and funerals - "no one used to expect to be paid for that kind of help earlier. And now it's just not necessary, because many families started using [the services of] funeral homes. They hire a cafe for the catering of the post-funeral mourning dinner. Weddings are also rarely celebrated at home these days. This trend began around ten years ago".

Daily communication and the gathering for calendar and family celebrations strengthen neighbourly relations. For most respondents, this means mutual support and being on friendly terms. On the other hand, a reduction in neighbourly links must also be acknowledged, first of all to the detriment of close neighbourly relations. A majority of those interviewed admitted that over the perspective of time, social contact with their neighbours had decreased. This phenomenon was usually accompanied by a change in neighbours, either when 
new ones moved in, or they themselves moved elsewhere to live. Modern life in the village or the city is not noted for being sedentary. For example, according to a Polish woman from Trakai who was born in 1970, she currently lives in an apartment building where the old neighbours say hello to one another, whereas the new inhabitants do not. In her parents' generation "a different kind of friendship existed amongst neighbours. There were shared celebrations, communal work, but now each person keeps to themselves". A Polish woman from Marijampolis born in 1954 says that when she used to live in an apartment building, she was closer to one neighbour with whom she would celebrate birthdays, sometimes other festivals as well, but now that she lives in a private house, she has no close neighbours with whom she spends more time with than her earlier neighbours. According to a Lithuanian woman born in 1953, when she lived in Musninkai, she was so close to one particular neighbour that they became proper friends. They visited one another, celebrated birthdays together. But when she moved to Kernave, her neighbours obviously changed. She gets along with her closest neighbours, especially one particular family, but there are also others nearby with whom she would not want to be friends at all, because one neighbouring family drinks alcohol excessively, another is known for spreading rumours about the other neighbours, etc. So, there is also the downside to neighbourly relations which can be a source of inconvenience or not inspire the desire to foster close neighbourly relations. The weakening of such relations is also affected by rapid modernisation processes that make it possible to remain independent from others living nearby, leading to the development of alienation.

\section{Conclusions}

Research into the types of community customs in the second half of the $20^{\text {th }}$ century and the early $21^{\text {st }}$ century in villages, towns, and cities near Vilnius allowed me to distinguish two types of neighbourhoods: distant (official) and close (informal) neighbourhoods. The first was determined by territorial proximity, the second is revealed in more than just territory but also a group formed around common interests, who are free to choose to spend leisure time or celebrate special occasions together. Whilst analysing the ritual year as a space where neighbours can gather, close relations are an important factor. These relations are expressed in a similar way in various types of settlements. Not only in villages but in the city as well, good relations between neighbours are not limited 
exclusively to offering obligatory mutual assistance, but also include spending leisure time and celebrations together of the neighbours' own free will.

Research of distant relations in neighbourhoods showed that being of different nationalities or faiths did not play a role in the formation of mutual neighbourly relations. One's living surrounds, their plot of land and a farm that required constant maintenance were more important in upholding neighbourly relations. A close neighbourhood based on spending leisure time and celebrations together could in some cases determine certain differences between neighbours of different religions. The religious nature of certain celebrations limits neighbours of different faiths from spending time together at these celebrations. Neighbours of all nationalities and faiths do gather to celebrate the New Year and birthdays, the same can also happen during other non-religious celebrations. Christian neighbours usually come together on the occasion of name days, Christmas, Easter, and on religious feast days. The greatest differences in how neighbours get along are revealed over the perspective of time. The younger generation's views towards neighbours differ from those held by older people. A reduction in good neighbourly relations does admittedly exist, to the detriment of a close neighbourhood. People from the older generation notice major shifts that have taken place within the last few decades. The weakening of social relations between neighbours is influenced by the age of respondents, changing neighbours, and rapid modernisation processes that make it possible to remain independent of people living nearby.

\section{Notes}

1 One article on neighbourhoods in this region has already been published (PaukštytèŠakniene 2018: 35-62). It was based on answers from 24 respondents from Marijampolis, Nemėžis and Kernave. The scope of research for this article was doubled, analysing the situation in villages, a town, and in larger cities as well. Unlike this article, the previous one did not focus on the analysis of the ritual year.

2 The article by Žilvytis Šaknys and Daiva Lapinskaite mentioned the tradition of neighbours making Easter tymbyl unleavened bread together, and even the belief that if someone visited seven neighbours and tried their tymbyl, they would marry soon (Šaknys, Lapinskaitė 2008: 85). 


\section{References}

Bauman,Zygmunt 2001. Community: Seeking Safety in an Insecure World. Cambridge: Polity. Bylaitė-Žakaitienè, Andželika 2012. Lietuvių etiketas ir bendravimo kultūra XX amžiuje [Lithuanian Etiquette and Communication Culture in the $20^{\text {th }}$ Century]. Klaipeda: Klaipėdos universiteto leidykla.

Čepaitienè, Auksuolè 2013. Gyvenimo etnografija: vietos, struktūros ir laikas. Besikeičianti Lietuva XX amžiuje [The Ethnography of Life: Places, Structures and Time. Changing Lithuania in the $20^{\text {th }}$ Century]. Vilnius: LII leidykla.

Eriksen, Thomas Hylland 2001. Small Places, Large Issues. An Introduction to Cultural and Social Anthropology. London, Sterling: Pluto Press.

Laučkaitè, Laima 2009. Vilniaus šventès ir pramogos XX a. pradžioje [Holidays and Entertainment in the Beginning of $20^{\text {th }}$ Century]. In: A. Lapinskienè (ed.) Imperinis Vilnius (1795-1918): kultūros riboženkliai ir vietinès tapatybès [Imperial Vilnius (1795-1918): Cultural Landmarks and Indigenous Identities]. Vilnius: Lietuvių literatūros ir tautosakos institutas, pp. 134-150.

Mardosa, Jonas 2013. Šventès mieste: keletas kūrimo ir funkcionavimo problemų [Festivals in the City. Some Creational and Functional Problems]. In: J. Mardosa (ed.) Šventés šiuolaikiniame mieste. Festivals in the Modern City. Vilnius: Edukologija, pp. 52-60.

Mažiulis, Antanas 1940. Iš žmonių tarpusavio santykių [From Human Relationships]. Gimtasai kraštas, Vol. 3-4, pp. 242-246.

Mažiulis, Antanas 1941. Moterų tarpusavès papročiai [Women's Mutual Customs]. Gimtasai kraštas [Native Land], Vol. 1-2, pp. 91-96.

Mažiulis, Antanas 1957. Kaimynystė [Neighbourhood]. In: Lietuvių enciklopedija [Lithuanian Encyclopedia], Vol.20. Boston: Lietuvių enciklopedijos leidykla, pp. 243-244.

Paukštytė-Šaknienè, Rasa 2016. Šeima ir kalendorinès šventès sovietinèje Lietuvoje [Family and Calendar Holidays in Soviet Lithuania]. Lietuvos etnologija. Socialinés antropologijos ir etnologijos studijos, Vol. 16 (25), pp. 9-34.

Paukštytė-Šaknienė, Rasa 2018. Kaimynystès ryšiai šių dienų kultūroje: atvejis iš Vilniaus apylinkių [Neighbourly Ties in Contemporary Culture: Cases from the Vilnius Area]. Lietuvos etnologija: Socialines antropologijos ir etnologijos studijos, Vol. 18 (27), pp. 35-61.

Plasseraud, Yves 2006. Mažumos. Tautiniu ir etninių mažumu studiju ivvadas [Minorities. Introduction to Ethnic and Ethnic Minority Studies]. Vilnius: Apostrofa. / Plasseraud, Yves 1998. Les minorités. Paris: Montchrestien.

Puodžiukienè, Dalè 2014. Politinių, ekonominių ir socialinių veiksnių ịtaka Lietuvos žemèvaldos ir apgyvendinimo struktūrų raidai nuo seniausiųjų laikų iki 1917 [The Influence of Political, Economic, and Social Factors on the Development of Land Management and Housing Structures in Lithuania from Ancient Times 
to 1917]. In: Dalė Puodžiukienė (ed.) Lietuvos architektūros istorija 4. Lietuvos etnine architektūra nuo seniausiuju laiku iki $1918 \mathrm{~m}$. [History of Lithuanian Architecture. Book 4. Ethnic Architecture from Ancient Times to 1918]. Vilnius: Savastis, pp. 10-23.

Rao, Ursula 2008. Ritual in Society. In: J. Kreinath \& J. Snock \& M. Stausberg (eds.) Theorizing Rituals. Classical Topic. Theoretical Approaches, Analytical Concepts. Leiden, Boston: Brill, pp. 143-160.

Rösener, Werner 2000. Valstiečiai Europos istorijoje [Peasants in European History]. Vilnius: Baltos lankos.

Šaknys, Žilvytis 2016. Ethnic and Confessional Aspects of a Holiday in the City of Vilnius. In: G. Stoliarova \& I. Sedakova \& N. Vlaskina (eds.) The Ritual Year 11. Traditions and Trasformation. Kazan-Moscow: T8, pp. 258-270.

Šaknys, Žilvytis 2019. Draugystè. Draugų bendrijų konstravimo ir palaikymo formos mieste, [Friendship. The Formation and Maintenance of Communities of Friends in the City]. In: Ž. Šaknys (ed.), Rasa Paukštytė-Šakniene \& Žilvytis Šaknys \& Irma Šidiškienè Vilniečiu socialine sq̨veika ir kultūriné raiška: laisvalaikis, šventes ir ritualai [The Social Interaction and Cultural Expression of Vilnius Residents: Leisure Time, Celebrations and Rituals]. Vilnius: Lietuvos istorijos institutas, pp. 195-281.

Šaknys, Žilvytis \& Lapinskaitè, Daiva 2008. Lietuvos karaimai: etninis ir konfesinis tapatumas XX a. antrojoje puseje ir XXI a. pradžioje [Lithuanian Karaims: Ethnic and Confessional Identity in the Late Twentieth - Early Twenty-First Century]. Lietuvos etnologija. Socialinés antropologijos ir etnologijos studijos, Vol. 8 (17), pp. 73-96.

Shanin, Teodor 1990. Defining Peasants. Essays Concerning Rural Societies, Expolary Economies, and Learning from them in the Contemporary World. Cambridge: Basil Blackwell.

Tönnies, Ferdinand 2001. Community and Civil Society. J. Harris (ed.). Cambridge: Cambridge University Press.

Udraitè, Eglè 2016. Kupiškènų bendruomenè ir jos gyvenimas XX amžiuje [Community of Kupiškis District and its Life in the $20^{\text {th }}$ Century]. In: A. Jonušytė (ed.) Kupiškis [Kupiškis district]. Vilnius: Versmè, pp. 918-926.

Vyšniauskaitė, Angelè 1964. Kaimo buitis ir papročiai [Rural Life and Customs]. In: A. Vyšniauskaitė (ed.) Lietuvių etnografijos bruožai [Lithuanian Ethnography]. Vilnius: Valstybinè politinès ir mokslinès literatūros leidykla, pp. 527-550.

Rasa Paukštytè-Šaknienè, PhD, Senior Researcher at the Department of Ethnology and Anthropology, Lithuanian Institute of History, Vilnius, Lithuania. Her research interests are in the field of traditional and modern culture, family, neighborhood, ethnic minorities, ethnology of city, the history of ethnology and festivity. She has field works in Lithuania, Byelorussia, Poland, Latvia and Bulgaria. 